\title{
Induction of precocious puberty in ewe lambs by pulsatile administration of GnRH
}

\author{
K. G. Pirl and T. E. Adams \\ Department of Animal Science, University of California, Davis, CA 95616, U.S.A.
}

\begin{abstract}
Summary. Circhoral administration ( $250 \mathrm{ng} / \mathrm{h}$, i.v.) of $\mathrm{GnRH}$ induced a preovulatorylike surge of $\mathrm{LH}$ and subsequent luteal function in 4 of 4 ewe lambs 1 month before expected date of puberty. Within $12 \mathrm{~h}$ of the start of pulsatile delivery of $\mathrm{GnRH}$, mean concentrations of immunoactive and bioactive $\mathrm{LH}$ increased significantly $(P<0.05)$ and the LH surge occurred by $1.8 \pm 0.6$ days of treatment. Mean concentrations of serum progesterone were elevated significantly $(P<0.001) 3$ days after the surge. The biopotency of $\mathrm{LH}$ (bioactive $\mathrm{LH} / \mathrm{imm}$ moactive $\mathrm{LH}$ ) before the $\mathrm{GnRH}$-induced surge of $\mathrm{LH}$ did not differ from LH biopotency in ewe lambs receiving circhoral delivery of saline $(0.41 \pm 0.05$ and $0.46 \pm 0.04$, respectively). Biopotency of LH declined markedly at the GnRH-induced LH surge $(0 \cdot 25 \pm 0 \cdot 04)$, but biopotency of serum LH was significantly augmented $(P<0.05)$ during the period of luteal activity $(0 \cdot 70 \pm 0 \cdot 07)$. Regular oestrous cycles were observed in 3 of 4 ewe lambs after the 10day GnRH treatment period. These results indicate that pulsatile delivery of GnRH is effective in inducing precocious puberty in ewe lambs. Increase in LH biopotency does not appear to be required in the pubertal transition to reproductive cyclicity in this species. Augmented LH biopotency may be important in support of luteal function after first ovulation.
\end{abstract}

\section{Introduction}

A key determinant modulating the onset of puberty in ewe lambs is completion of neuroendocrine integration (Foster et al., 1985). In this species (Foster \& Ryan, 1981), as in others (Wildt et al., 1980; Bourguignon \& Franchimont, 1984), the hypothalamus appears to be the limiting tissue during the reproductive quiescence that attends the prepubertal period. Indeed, ovarian and hypophysial tissues of ewe lambs are fully capable of sustained function by 9-12 weeks of age (Foote \& Bennett, 1968; Foster et al., 1975a; Riggall et al., 1983). In contrast, the dynamic pattern of luteinizing hormone (LH) secretion and the positive gonadotrophin response to oestradiol increase progressively during the prepubertal period (Foster et al., 1975b; Foster \& Karsch, 1975).

An increase in the frequency and amplitude of gonadotrophin secretion appears to drive the ovarian events that lead to first ovulation in ewe lambs. Indeed, imposition of an exogenous $\mathrm{LH}$ delivery system in the ewe lamb is effective in inducing precocious puberty when the frequency of LH delivery increases to a circhoral (hourly) pattern (Foster et al., 1984). Increased episodic release of the hypothalamic peptide gonadotrophin-releasing hormone (GnRH) is associated with puberty in male rodents (Bourguignon \& Franchimont, 1984) and circhoral delivery of exogenous GnRH induces precocious puberty in primates (Wildt et al., 1980). Furthermore, the increased amplitude and frequency of episodic secretion of $\mathrm{LH}$ that attends onset of puberty in primates is accompanied by increased biological activity of the secretory forms of LH (Lucky et al., 1980).

The present experiments were undertaken (1) to induce precocious puberty in ewe lambs by imposition of an exogenous $\mathrm{GnRH}$ pulse generator that delivers the hypothalamic peptide in a circhoral manner, and (2) to determine the quantitative and qualitative changes in secretory $\mathrm{LH}$ that attend GnRH-induced ovulation in ewe lambs. 


\section{Materials and Methods}

Animals. The 8 crossbred ewe lambs (3/4 Rambouillet, 1/4 Dorset or 1/4 Finnish Landrace) used were born in late January, weaned at 8-10 weeks of age, and thereafter raised on alfalfa pasture at the University of California sheep facility.

Treatments. At 25 weeks of age ewe lambs were transferred to a central open-sided barn and fed alfalfa pellets ad libitum. After 2 weeks, cannulae (Intramedic, PE 90, Clay Adams, Parsippany, NJ, U.S.A.) were inserted in the left external jugular vein to a depth of $16 \mathrm{~cm}$. Distal to the site of entry, cannulae were sheathed in large diameter plastic tubing. Cannulae and protective sheath were passed along the head via the halter and along a $1.5 \mathrm{~m}$ lead rope. Ewe lambs were housed in pairs in indoor stalls on an $18 \mathrm{~h}$ light:6h dark cycle (lights on at 06:00 h). Lambs were freely mobile at the end of the $1.5 \mathrm{~m}$ lead, allowing access to alfalfa pellets and water. The cannulae were connected to 3-ml syringes in a Harvard infusion pump. The pump was connected to an automatic timer that was activated for 6 min every hour to effect intravenous delivery of $250 \mathrm{ng} \mathrm{GnRH}$ (US Biochemical, Cleveland, OH, U.S.A.) in saline (0.9\% $(w / v) \mathrm{NaCl}, \mathrm{N}=4)$ or an equivalent volume $(0.5 \mathrm{ml})$ of saline alone $(\mathrm{N}=4)$. The mean age of saline- and $\mathrm{GnRH}-$ treated lambs at the start of treatment was $196.7 \pm 1.6$ days and $196.7 \pm 1.8$ days, respectively. The ewe lambs remained on the infusion system for 10 days.

Data collection. Blood sampling was begun 10 days before infusion. Daily blood samples (5 ml) were withdrawn from each animal by jugular venepuncture between 08:00 and 10:00 h. During the 60 days after treatment, daily blood samples were also collected. During the period of pulsatile GnRH delivery blood samples were collected at 6-h intervals, with sample collection 45-50 min after the GnRH pulse. Samples were immediately placed on ice and allowed to clot. Serum was isolated by centrifugation $(2200 \mathrm{~g}$ for $30 \mathrm{~min})$ at $4^{\circ} \mathrm{C}$. Serum was rapidly frozen in a solid $\mathrm{CO}_{2}$-acetone bath and stored at $-20^{\circ} \mathrm{C}$ until analysis. The incidence of behavioural oestrus (willingness to stand immobile during mount and intromission of vasectomized ram) was evaluated daily for 60 days after treatment.

Hormonal analyses. Serum concentrations of immunoactive LH and progesterone were determined using previously validated radioimmunoassay procedures (Adams et al., 1975; Gibori et al., 1977). The reference standards for the LH and progesterone assays were NIAMDD-oLH-23 and crystalline progesterone (Sigma, St Louis, MO, U.S.A.), respectively. In these assay systems the minimum levels of detectable $\mathrm{LH}$ and progesterone were $0.2 \mathrm{ng} / \mathrm{ml}$ and $0.1 \mathrm{ng} / \mathrm{ml}$ respectively. Each hormone determination was performed in duplicate. Intra-assay coefficients of variation for progesterone and LH radioimmunoassays were $5 \cdot 3 \%$ and $8 \cdot 2 \%$, respectively. The progesterone extraction efficiency was $87 \%$. Serum concentrations of progesterone were not adjusted to account for loss during extraction. The biological activity of LH was assessed using the mouse interstitial cell testosterone (MICT) bioassay detailed previously (Ellinwood et al., 1980) as modified by Adams et al. (1986). This assay used NIAMDD-oLH-23 as the LH standard and had a minimum level of detection of $0.2 \mathrm{ng} \mathrm{LH} / \mathrm{ml}$. The intra-assay coefficient of variation was $3.4 \%$ and all hormone measurements were performed in the same assay.

Data analysis. The effect of pulsatile delivery of GnRH or saline on serum concentrations of immunoactive and bioactive $\mathrm{LH}$ and progesterone was evaluated by analysis of variance for repeated measures and Tukey's HSD test (Gill, 1978). In addition, data from GnRH-treated ewe lambs were re-analysed by these same methods after normalization relative to the time of the preovulatory-like surge of immunoactive LH. A surge of immunoactive LH was defined as a serum concentration of LH that exceeded the within-animal mean by 3 standard deviations. A surge of LH which was followed by evidence of sustained luteal activity (serum concentrations of progesterone greater than $0.5 \mathrm{ng} / \mathrm{ml}$ for 4 consecutive days) was defined as a preovulatory-like surge of immunoactive $\mathrm{LH}$.

\section{Results}

Pulsatile delivery of GnRH induced a preovulatory-like surge of immunoactive LH and sustained elevation of serum progesterone in all 4 prepubertal ewe lambs (Fig. 1a). In contrast, neither surgelike secretion of immunoactive $\mathrm{LH}$ nor augmented secretion of progesterone were evident in lambs receiving pulsatile delivery of saline (Fig. 1b). Immediately before the start of treatment, serum concentrations of immunoactive and bioactive LH were at or below the limits of detection for the respective assays $(0.2 \mathrm{ng} / \mathrm{ml})$ for the saline and $\mathrm{GnRH}$ treated ewe lambs. Within $12 \mathrm{~h}$ of the start of GnRH treatment, serum concentrations of immunoactive and bioactive LH $(3.4 \pm 0.8 \mathrm{ng} / \mathrm{ml}$ and $1.03 \pm 0.07 \mathrm{ng} / \mathrm{ml}$, respectively) were significantly $(P<0.05)$ higher than in saline-treated lambs $(1.2 \pm 0.4 \mathrm{ng} / \mathrm{ml}$ and $0.51 \pm 0.20 \mathrm{ng} / \mathrm{ml}$, respectively). Furthermore, circhoral delivery of GnRH induced a preovulatory-like surge of immunoactive $\mathrm{LH}$ in each of the treated lambs $1.8 \pm 0.6$ days after start of GnRH treatment.

Parallel increases in bioactive $\mathrm{LH}$ accompanied the elevations of immunoactive $\mathrm{LH}$ during the $\mathrm{GnRH}$-induced gonadotrophin surge. Serum concentrations of bioactive LH increased to $0 \cdot 9 \pm$ 

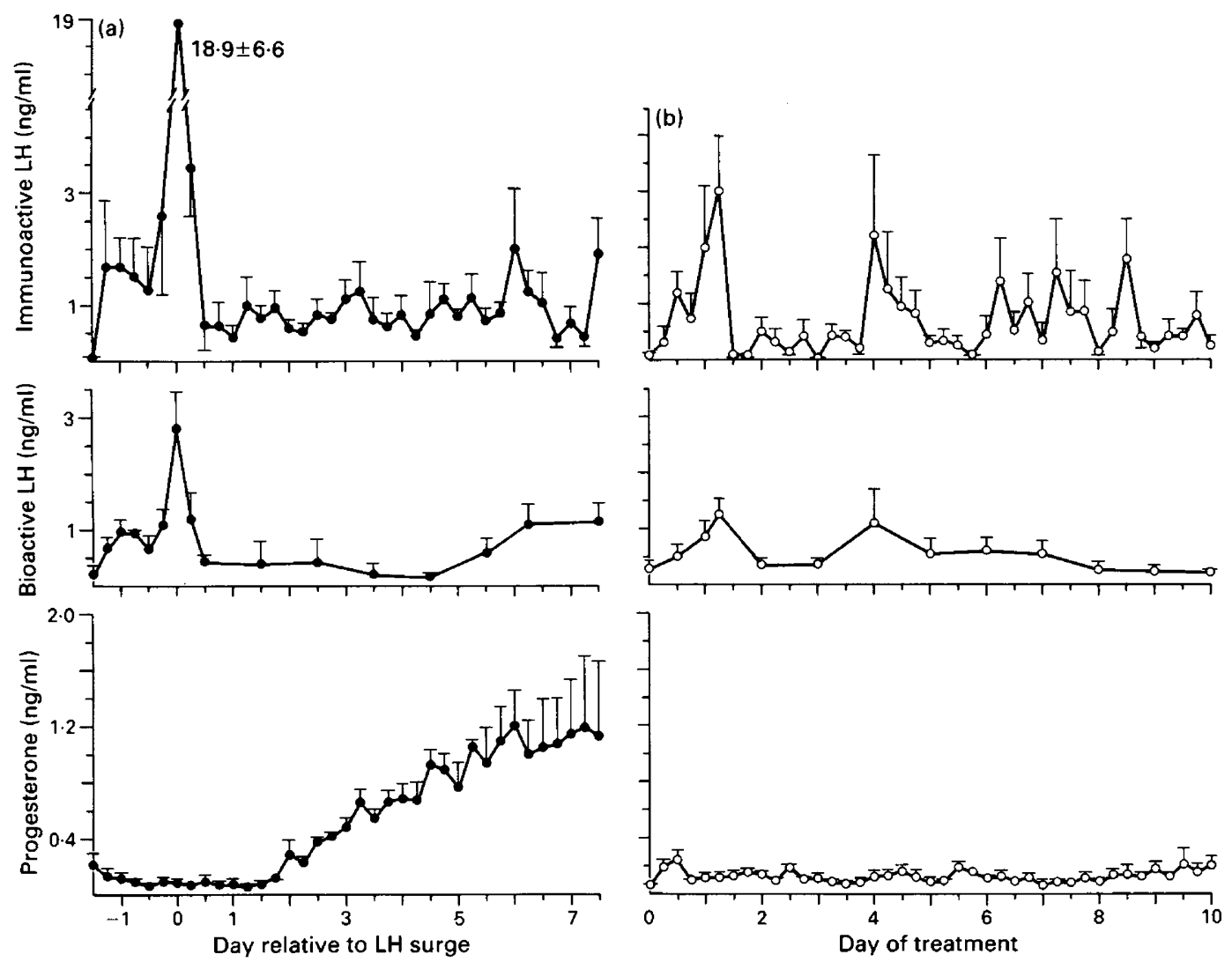

Fig. 1. Serum concentrations (mean \pm s.e.m.) of progesterone and bioactive and immunoactive LH (a) in 4 prepubertal ewe lambs during prolonged circhoral administration of GnRH ( $250 \mathrm{ng} / \mathrm{h}$ pulse) and (b) in 4 prepubertal ewe lambs receiving pulsatile delivery of saline. In (a) values are normalized relative to the time of the surge of immunoactive LH. In (b) values are presented relative to the start of saline delivery.

$0.2 \mathrm{ng} / \mathrm{ml} 24 \mathrm{~h}$ before the immunoactive LH surge (Fig. 1a). At the height of the preovulatorylike surge of $\mathrm{LH}$, serum concentrations of immunoactive and bioactive $\mathrm{LH}$ were $18.9 \pm 6.6 \mathrm{ng} / \mathrm{ml}$ and $2.6 \pm 0.7 \mathrm{ng} / \mathrm{ml}$, respectively.

The mean biopotency of $\mathrm{LH}$ (bioactive $\mathrm{LH} /$ immunoactive $\mathrm{LH}$ ) during the infusion period in the saline-treated lambs was $0.46 \pm 0.04$. In lambs exposed to pulsatile delivery of $\mathrm{GnRH}$, secretory forms of LH exhibited a biopotency of $0.41 \pm 0.05$ during the $24 \mathrm{~h}$ period immediately before the preovulatory-like surge of $\mathrm{LH}$. When expressed relative to the $\mathrm{LH}$ biopotency during the immediate presurge period, the biopotency of LH was significantly $(P<0.05)$ depressed during the surge $(0.25 \pm 0.04)$ and significantly $(P<0.05)$ increased during the period of augmented progesterone secretion that followed the surge $(0 \cdot 70 \pm 0 \cdot 07)$.

Serum concentrations of progesterone were significantly $(P<0.05)$ elevated above pretreatment levels $(0 \cdot 10 \pm 0.01 \mathrm{ng} / \mathrm{ml})$ within 3 days of the $\mathrm{GnRH}$-induced preovulatory-like surge $(0.5 \pm 0.1 \mathrm{ng} / \mathrm{ml})$. Six days after the $\mathrm{GnRH}$-induced surge, mean serum concentration of progesterone was $1.2 \pm 0.3 \mathrm{ng} / \mathrm{ml}$ (Fig. la). In contrast, mean serum concentrations of progesterone in saline-treated lambs did not exceed $0 \cdot 25 \mathrm{ng} / \mathrm{ml}$ (Fig. 1b).

A preovulatory-like surge of $\mathrm{LH}$ and subsequent sustained luteal function suggested that ovulation was induced by pulsatile delivery of GnRH in all $4 \mathrm{GnRH}$-treated lambs. Three lambs 
continued to display regular oestrous cycles after the period of GnRH infusion. However, none of the control lambs ovulated during the period of saline infusion. The average age of first ovulation in GnRH- and saline-treated ewe lambs was $201 \pm 3$ days and $242 \pm 9$ days respectively.

\section{Discussion}

Periods of reproductive quiescence induced by environmental variables commonly reflect variation in function at hypothalamic loci leading to reduced activity of the endogenous GnRH pulsegenerating mechanism (Karsch et al., 1984). Imposition of an exogenous GnRH pulse delivery system can therefore override seasonal (McLeod et al., 1982) and post-partum (Wright et al., 1984) anoestrus in sheep.

The reproductive quiescence that attends the prepubertal period has also been ascribed to suppression of the hypothalamic GnRH pulse-generating mechanism (Foster et al., 1985). Indeed, an increase in frequency and amplitude of episodic secretion of LH attends the onset of puberty in ewe lambs (Foster et al., 1975b). Moreover, episodic delivery of exogenous LH hastens the onset of puberty in this species (Foster et al., 1984).

The results presented here demonstrate that circhoral delivery of exogenous GnRH, like pulsatile delivery of LH itself, is effective in inducing precocious puberty in ewe lambs. Similar effects of imposition of an exogenous GnRH pulse generator have been noted in prepubertal primates (Wildt et al., 1980). These data lend support to the postulate that onset of puberty is dependent on maturation of hypothalamic centres capable of episodic release of GnRH with an hourly frequency (Foster et al., 1985).

The increased activity of the hypothalamic GnRH pulse generator during the prepubertal period increases serum concentrations of immunoactive LH (Foster \& Ryan, 1981) and may also modify the qualitative character of the secretory forms of LH. In primates the biological activity of LH serves as a more sensitive measure of progress toward puberty than does immunoactive LH (Lucky et al., 1980; Reiter et al., 1982). In humans, the onset of puberty is associated with a 20-fold increase in serum concentration of bioactive LH. In contrast, serum concentrations of immunoactive LH increase only 5-fold during the same transitional period (Lucky et al., 1980). In primates, therefore, puberty is associated with increased serum concentrations of LH and augmented biopotency of secretory forms of LH (Williams et al., 1982).

As we report here, GnRH-induced ovulation in prepubertal lambs is accompanied by increased serum concentrations of both immunoactive and bioactive LH. However, the biopotency of LH in saline-treated prepubertal lambs did not differ from that in GnRH-treated lambs before the induced preovulatory surge of LH. Indeed, the biopotency of LH secreted during the GnRHinduced preovulatory surge was significantly reduced relative to LH biopotency in prepubertal lambs. These results indicate that increased secretion of LH during the onset of puberty in lambs need not be coupled with augmented biopotency of serum LH.

The marked decline in LH biopotency during the GnRH-induced preovulatory surge of LH in ewe lambs is noteworthy. A similar depression in LH biopotency has been demonstrated during the preovulatory surge in adult, cyclic ewes (Adams et al., 1987) and in women (Dufau et al., 1976). This decline in the biological activity of LH during periods of high secretion may represent a temporary disruption of the intracellular division between pools of mature and immature LH.

In contrast, the biopotency of LH was significantly increased during the luteal phase in ewe lambs receiving circhoral delivery of GnRH. Similar augmentation of LH biopotency has been noted during the luteal phase in mares (Adams et al., 1986) and in women (Dufau et al., 1976). Therefore, although secretion of LH is minimal during the luteal phase, the biological activity of secretory forms of LH is increased. Such augmentation of LH biopotency may be necessary to maintain luteal function.

Taken together, these results indicate that imposition of an exogenous GnRH pulse generator 
in ewe lambs can induce ovulation and precocious puberty. In this species the onset of puberty is associated with increased serum concentrations of LH. However, the biological activity of secretory forms of $\mathrm{LH}$ does not change during the period leading to GnRH-induced first ovulation.

We thank Betty Adams, Debbie Cravin, Sarah Davis, and Rachel Brinkman for technical assistance; Dr G. D. Niswender, Dr T. M. Nett and the National Hormone and Pituitary Program for assay reagents; and Cheryl Johnson and Jane Hamiel for editorial assistance. Supported by NIH grant HD17141 and the California Agricultural Experiment Station. Submitted in partial fulfilment of the requirements for the Master of Science degree (K.G.P.).

\section{References}

Adams, T.E., Kinder, J.E., Chakraborty, P.K., Estergreen, V.L. \& Reeves, J.J. (1975) Ewe luteal function influenced by pulsatile administration of synthetic LHRH/FSH-RH. Endocrinology 97, $1460-1467$.

Adams, T.E., Horton, M.B., Watson, J.G. \& Adams, B.M. (1986) Biological activity of luteinizing hormone (LH) during the estrous cycle of mares. Dom. Anim. Endocr. 3, $69-77$.

Adams, T.E., Adams, B.M. \& Watson, J.G. (1987) Secretory dynamics of bioactive and immunoactive $\mathbf{L H}$ during the oestrous cycle of the sheep. J. Reprod. Fert. 79, 555-563.

Bourguignon, J-P. \& Franchimont, P. (1984) Pubertyrelated increase in episodic LHRH release from the rat hypothalamus in vitro. Endocrinology 114, 1941-1943.

Dufau, M.L., Beitins, I.Z., McArthur, J.W. \& Catt, K.J. (1976) Effect of luteinizing hormone releasing hormone (LHRH) upon bioactive and immunoactive serum LH levels in normal subjects. $J$. clin. Endocr. Metab. 43, 658-667.

Ellinwood, W.E., Brenner, R.M., Hess, D.L. \& Resko, J.A. (1980) Testosterone synthesis in rhesus fetal testes: a comparison between middle and late gestation. Biol. Reprod. 22, 955-963.

Foote, W.C. \& Bennett, J.A. (1968) Hormonal induction of fertile mating in the prepuberal ewe. J. Anim. Sci. 27, 1191, Abstr.

Foster, D.L. \& Karsch, F.J. (1975) Development of the mechanism regulating the preovulatory surge of luteinizing hormone in sheep. Endocrinology 97, 1205-1209.

Foster, D.L. \& Ryan, K.D. (1981) Endocrine mechanisms governing transition into adulthood in female sheep. J. Reprod. Fert., Suppl. 30, 75-90.

Foster, D.L., Jaffe, R.B. \& Niswender, G.D. (1975a) Sequential patterns of circulating $\mathbf{L H}$ and FSH in female sheep during the early postnatal period: Effect of gonadectomy. Endocrinology 96, 15-22.

Foster, D.L., Lemons, J.A., Jaffe, R.B. \& Niswender, G.D. (1975b) Sequential patterns of circulating luteinizing hormone and follicle-stimulating hormone in female sheep from early postnatal life through the first estrous cycles. Endocrinology 97, 985-994.

Foster, D.L., Ryan, K.D. \& Papkoff, H. (1984) Hourly administration of luteinizing hormone induces ovulation in prepuberal female sheep. Endocrinology 115, 1179-1185.
Foster, D.L., Yellons, S.M. \& Olster, D.H. (1985) Internal and external determinants of the timing of puberty in the female. J. Reprod. Fert. 75, 327-344.

Gibori, G., Antczak, E. \& Rothchild, I. (1977) The role of estrogen in the regulation of luteal progesterone secretion in the rat after day 12 of pregnancy. Endocrinology 100, 1483-1495.

Gill, J.L. (1978) Design and Analysis of Experiments in the Animal and Medical Sciences. Iowa State University Press, Ames.

Karsch, F.J., Bittman, E.L., Foster, D.L., Goodman, R.L., Legan, S.J. \& Robinson, J.E. (1984) Neuroendocrine basis of seasonal reproduction. Recent Prog. Horm. Res. 40, 185-232.

Lucky, A.W., Rich, B.H., Rosenfield, R.L., Fang, V.S. \& Roche-Bender, N. (1980) LH bioactivity increases more than immunoreactivity during puberty. $J$. Pediatr. 97, 205-213.

McLeod, B.J., Haresign, W. \& Lamming, G.E. (1982) The induction of ovulation and luteal function in seasonally anoestrous ewes treated with small-dose multiple injections of GnRH. J. Reprod. Fert. 65, 215-221.

Riggall, F.C., Abrams, R.M., Kalra, P.S., Cantor, B. \& Spellacy, W.N. (1983) Changes in the LH response to GnRH in the ovine fetus and neonate. $J$. Reprod. Med. 28, 325-329.

Reiter, E.O., Beitins, I.Z., Ostrea, T. \& Gutai, J.P. (1982) Bioassayable luteinizing hormone during childhood and adolescence and in patients with delayed pubertal development. J. clin. Endocr. Metab. 54, 155-161.

Wildt, L., Marshall, G. \& Knobil, E. (1980) Experimental induction of puberty in the infantile female rhesus monkey. Science, N.Y. 207, 1373-1375,

Williams, R.F, Turner, C.K. \& Hodgen, G.D. (1982) The late pubertal cascade in perimenarchial monkeys: onset of asymmetrical ovarian estradiol secretion and bioassayable luteinizing hormone release. J. clin. Endocr. Metab. 55, 660-665.

Wright, P.J., Geytenbeek, P.E., Clarke, I.J. \& Findlay, J.K. (1984) Induction of plasma LH surges and normal luteal function in acyclic post-partum ewes the pulsatile administration of LH-RH. J. Reprod. Fert. $71,1-6$. 